\title{
Sam Murray
}

\section{Breaking the Link Between Disability and Child and Whānau Poverty}

\section{Abstract}

In New Zealand, disabled children are more likely to live in a oneparent household than are non-disabled children. The primary carers of disabled children have a higher unemployment rate than oneparent households in general. As a result, households with disabled children are significantly more likely to experience income poverty. This is not the case in the United Kingdom, where households with disabled children tend not to be at greater risk of income poverty. A key factor in preventing a greater risk of income poverty is the higher disability-related allowances in the United Kingdom: the median payment rate is almost three times higher than the New Zealand equivalents. There is a clear case for increasing the payment rate of the New Zealand disability-related allowances. There is also a clear case for an overhaul of support for households with disabled children to better enable carers/parents to work and to provide more equitable and effective support.

Keywords child poverty, disabled children, children with disabilities, one-parent households, unemployment, United Kingdom, Ongoing Resourcing Scheme

\footnotetext{
Samuel Murray is the National Policy Coordinator for CCS Disability Action, based in Dunedin.
}

T n New Zealand, having a disabled child increases your chances of living in a low-income household. The key point of this article is that the link between poverty and disability can, and should, be broken. In the United Kingdom, disability-related allowances appear to be more effective at reducing the higher risk of poverty than their New Zealand equivalents. Alongside better support to enable parents/carers of disabled children to work, if they choose, higher disabilityrelated allowances would reduce, or eliminate, the increased risk of poverty for households with disabled children.

Disability has been the focus of several reports in New Zealand on child poverty. Donna Wynd, for example, wrote a monograph for the Child Poverty Action Group on children, disability and poverty (Wynd, 2015). The Expert Advisory Group on Solutions to Child Poverty focused their 21 st working paper on child poverty and disability (Expert Advisory Group on Solutions to Child Poverty, 2012). Jessica Suri and Alan Johnson have researched the uptake of the child disability allowance (Suri and Johnson, 2016). 
This article builds on the existing work by combining the available information with unpublished data from the 2013 Disability Survey and data from the Ministry of Education's Ongoing Resourcing Scheme (ORS), which is for students with high and very high learning support needs. It also compares United Kingdom and New Zealand data on household income and disabled children, as well as the disability-related allowances available in each country.

\section{Limitations}

This article's primary purpose is to expand the data and analysis available on child poverty and disability in New Zealand. The article makes some preliminary suggestions for ways to reduce the high rate of income poverty that disabled children and their whānau experience in New Zealand. It is only a starting point, however, and the subject deserves far more in-depth treatment. This article also has a limited focus on selected socio-economic indicators and household income, and does not seek to examine the diversity among disabled children and their whānau or the depth of their experiences in society.

\section{Terminology}

The United Nations Convention on the Rights of Persons with Disabilities (2008) uses the term 'children with disabilities'. The New Zealand disability strategies use the term 'disabled children' (New Zealand Government, 2001). These terms have a similar meaning, but can have a different emphasis. Using the term 'disabled people', or 'disabled children', stresses that a disability identity can be a source of pride and community for individuals. This is linked to a social model of disability which emphasises the role of society in creating the disadvantage and discrimination that disabled people experience. The disabled person is not the issue; the issue is the barriers and attitudes in society (Office for Disability Issues, 2016, p.13). This article uses the terminology of the New Zealand disability strategies.

Poverty in this article refers to the income of households being a certain percentage below the median household income (three different thresholds are used). This can be more accurately defined

\section{Box 1: Key findings}

In 2013:

New Zealand households with disabled children were significantly more likely to be in income poverty than all households. This was not the case in the United Kingdom.

- The median payment for children from disability-related allowances in New Zealand was NZ\$45.62 a week.

- The median payment for children from disability-related allowances in the UK was NZ\$134.36 a week.

- The disability-related allowances in the UK reduced the percentage of households with disabled children under one income poverty measure by four percentage points.

- $30 \%$ of the disabled children in New Zealand lived in one-parent households. $86 \%$ of the disabled children in New Zealand who lived in households earning less than $\$ 30,000$ a year were in one-parent households.

- The unemployment rate of primary carers of disabled children in New Zealand was $17 \%$.

$63 \%$ of New Zealand households with disabled children say they earn just enough or not enough money.

\section{Between 2008 and 2017:}

Disabled New Zealand students who received support through the Ongoing Resourcing Scheme became more concentrated in lower decile schools.

In 2017:

Disabled New Zealand students who received ORS support made up $1.7 \%$ of all students in decile $1-5$ schools, compared to $0.7 \%$ of all students in decile 6-10 schools.

as income poverty. Income poverty is ultimately an inadequate way to capture the full risks of financial and material hardship for households with disabled family members. This is because, as will be discussed, disability can generate additional costs. This means households with disabled family members can still experience hardship and profound disadvantage even at median, or higher, household income levels. The available data only allows us, however, to adequately examine income poverty.

\section{The number of disabled children in New Zealand}

The New Zealand 2013 Disability Survey estimated that there are around 95,000 disabled children up to the age of $14,11 \%$ of all children in this age group (Statistics New Zealand, 2014d). For children, the New Zealand Disability Survey uses a series of questions about the difficulty of undertaking certain activities, as well as more diagnostic questions, to determine if the child has a disability (Statistics New Zealand, 2015, p.23).

The definition of a child used in the New Zealand Disability Survey was an individual aged 0 to 14 (Statistics New Zealand, 2014e). Because different questions were asked in the child and adult versions of the survey, the two cannot be easily combined to provide accurate data for wider age ranges. As a result, there is no choice but to use the 0-14 age range for New Zealand Disability Survey data. Using wider age ranges would allow us to better match the eligibility criteria for support such as the child disability allowance and ORS, as well as definitions in domestic law and international conventions (the UN Convention on the Rights of the Child; the New Zealand Vulnerable Children Act 2014).

A smaller number of children access disability-related support. Looking at a similar time period to that covered by the 2013 Disability Survey, as of September 2013, 8,705 children and young people 
Figure 1: Percentage of households under each household income threshold 2013 (gross/total income before housing costs)

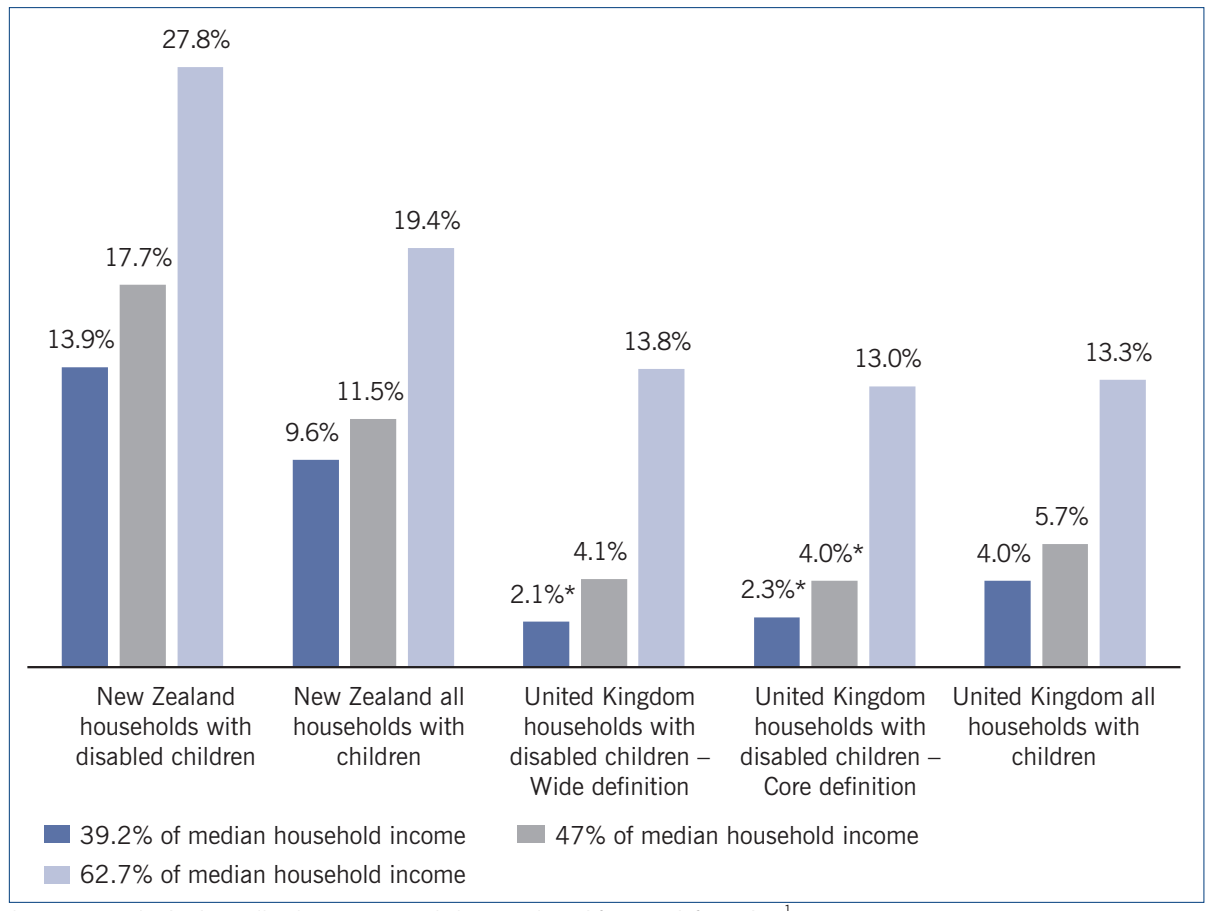

* means sample size is smaller than recommended, see endnote i for more information. ${ }^{1}$

Sources: Statistics New Zealand, 2014c, n.d.; UK Data Service, 2018

aged $0-14$ were receiving Ministry of Health-funded disability support services, although a significant number may be receiving only carer support (Ministry of Health, 2015, p.8). As of July 2013, 5,423 students aged $0-14$ were receiving ORS funding (Indicators and Reporting Team, Ministry of Education, 2017a).

\section{Poverty measures and disabled children}

Unfortunately, we have no New Zealand data available on disabled children and household disposable income (income after tax), household income after housing costs, or household income adjusted for household composition. This is because disability status is currently not collected in the Household Economic Survey. As a result, we are unable to use several key poverty measures to assess households with disabled children (Boston, 2017).

From the 2013 Disability Survey it is possible to get data on the total/gross household income of households with disabled children before housing costs. The survey data uses the 2013 census household income bands, which means precise matches to poverty lines are not possible. We can get relatively close, though: we have data on the number of households with disabled children that earn less than $\$ 25,001$ a year (this is $39.2 \%$ of median total/gross household income in the 2013 census), $\$ 30,000$ a year ( $47 \%$ of the median total/gross household income in the 2013 census) and $\$ 40,000$ a year $(62.7 \%$ of the median total/gross household income in the 2013 census) (Statistics New Zealand, 2014b, p.36).

\section{Comparing child poverty among}

disabled children in New Zealand

\section{and the United Kingdom}

International comparisons of data on disabled children are often difficult because of the different definitions and methodology used, particularly around disability (Blackburn, Spencer and Read, 2010, p.20). Some countries lack data on disabled children and household income: for example, no Australian data is available (Australian Council of Social Service and the Social Policy Research Centre, 2016, p.34). The United Kingdom, however, is one country that does collect statistics on disabled children and household income, through the annual Family Resources Survey. This provides an interesting comparison because, as the following section will look at, the United Kingdom has higher disability-related allowances than New Zealand. We must be mindful, however, of the differences between the data sources.
The two key differences between the New Zealand and UK data are the definitions of a child and of a disability. The definition of a child in the Family Resources Survey is an individual under 16 years of age, or an unmarried or noncohabiting 16-19-year-old in full-time non-advanced education (Department for Work and Pensions and Office for National Statistics, 2014b, pp.12, 44). As noted above, the 2013 Disability Survey uses the definition of an individual aged 0-14.

Different disability identification questions are also used in each survey, although both question sets are based, at least partially, on the World Health Organisation's International Classification of Functioning, Disability and Health (Office for National Statistics, 2015; Statistics New Zealand, 2015, pp.5, 10). The Family Resources Survey bases the thresholds for disability on the UK Equality Act 2010. There are two thresholds used: a core threshold, under which an estimated $7 \%$ of children have a disability, and a wide threshold, under which an estimated $13.4 \%$ of children have a disability (Department for Work and Pensions and Office for National Statistics, 2014a, p.61). As mentioned, the 2013 Disability Survey estimated that $11 \%$ of New Zealand children had a disability (Statistics New Zealand, 2014d). All three thresholds are used in Figure 1.

As Figure 1 shows, in New Zealand, households with disabled children are more likely to be in income poverty. This is not the case in the United Kingdom. The only exception is disabled children under the wide definition for the $62.7 \%$ threshold, where they have a slightly higher chance of being in income poverty.

\section{Comparing the disability-related} allowances available in New Zealand and the United Kingdom

The Committee on the Rights of Persons with Disabilities notes that financial support for family carers is crucial to counteract limited access to the labour market and the higher risk of poverty (Committee on the Rights of Persons with Disabilities, 2017, pp.1, 12-13). The Committee on the Rights of the Child similarly stresses the importance of children with disabilities being allocated 
adequate budgetary resources as well as having access to poverty reduction programmes (Committee on the Rights of the Child, 2007, p.2).

In New Zealand there are two disabilityrelated allowances available for disabled children. The disability allowance, which is also available for adults, and the child disability allowance. The disability allowance is means-tested and is designed to meet specific disability-related costs, such as doctors' fees, heating or medical alarm rental. The amount each child gets depends on the relevant disability-related costs identified, up to a maximum rate. The child disability allowance is not meanstested and is a fixed amount.

The UK equivalent of these allowances is the disability living allowance (DLA), which is divided into a care component and a mobility component. Neither component is means-tested. The care component has three payment rates and the mobility component has two payment rates. In the UK there are also disability tax credits for which disabled children and their family can qualify (Revenue Benefits, 2018). For a household which qualified for both types of disability tax credit elements, this could add another NZ\$144.56 per week to the household's income (National Archives, n.d.). There is no equivalent in New Zealand to these disability-specific tax credits; whānau with and without disabled children qualify for the same Working for Families tax credits.

A higher percentage of children in New Zealand receive at least one type of disability-related allowance. The allowances in the United Kingdom are, however, far higher. In 2013 a disabled child in New Zealand could receive a maximum of $\$ 106.16$ from disabilityrelated allowances per week, and \$60.54 of that is means-tested and only for specific purposes, compared with a maximum of \$244.06 per week in the United Kingdom. With both disability tax credit elements, the maximum in the UK is $\$ 388.62$ per week (National Archives, n.d.).

Further, very few children in New Zealand receive both allowances or anywhere close to the maximum amount for the disability allowance. In March 2013, 39,795 children received at least one of the two allowances, but only 4,710 children
Table 1: Disability-related allowances and tax credits in the United Kingdom and New Zealand in 2013

\begin{tabular}{lll}
\hline Type of allowance & $\begin{array}{l}\text { Percentage of all children/ } \\
\text { young people aged 17 and } \\
\text { under receiving disability- } \\
\text { related allowances }\end{array}$ & $\begin{array}{l}\text { Payment rate a week } \\
\text { in March 2013 NZ\$ }\end{array}$ \\
\hline UK DLA care and/or mobility & $3.0 \%$ & $\begin{array}{l}\$ 38.13-\$ 244.06 \\
\$ 134.36 \text { (median) }\end{array}$ \\
UK DLA care & $3.0 \%$ & $\$ 38.13-\$ 143.73$ \\
UK DLA mobility & $2.3 \%$ & $\$ 96.23$ (median) \\
$\begin{array}{l}\text { UK disabled child element (child tax } \\
\text { credit) }\end{array}$ & data not available & $\$ 38.13-\$ 100.33$ \\
$\begin{array}{l}\text { UK severely disabled child element } \\
\text { (child tax credit) }\end{array}$ & data not available & $\$ 38.13$ (median) \\
$\begin{array}{l}\text { New Zealand child disability } \\
\text { allowance and/or disability allowance }\end{array}$ & $3.8 \%$ & $\$ 103.01$ \\
$\begin{array}{l}\text { New Zealand child disability } \\
\text { allowance }\end{array}$ & $3.3 \%$ & $\$ 106.16$ (maximum) \\
$\begin{array}{l}\text { New Zealand disability allowance } \\
\text { N }\end{array}$ & $0.9 \%$ & $\$ 45.62$ (median) \\
\hline
\end{tabular}

Source: Department for Work and Pensions, 2013, 2018; Work and Income, 2013; Inland Revenue, 2013; Office for National Statistics, 2017; Stats New Zealand, 2018a; National Archives, n.d.; Official Information Act responses from the Ministry of Social Development

received both. The median rate of payment for children who received both allowances was just $\$ 60.12$, and for the disability allowance component just $\$ 14.50 .76 \%$ of the children who received a disabilityrelated allowance received just the child disability allowance of $\$ 45.62$ per week. As a result, $\$ 45.62$ is the median payment per week for children who received a disabilityrelated allowance in New Zealand. ${ }^{2}$

By comparison, in May 2013, 95\% of children who received the DLA received $\$ 76.26$ or more a week from the DLA; $80 \%$ of children received the DLA received $\$ 114.39$ or more a week from the DLA; $34 \%$ received $\$ 181.89$ or more a week; and $12 \%$ received the highest amount of $\$ 244.06$ per week. The median payment for children from the DLA was $\$ 134.36$ per week (Department for Works and Pensions, 2018)

The UK data allows us to exclude disability-related allowances from household income. Unfortunately, we can only do this for after-tax income adjusted for household composition, so we cannot directly compare the data with the New Zealand Disability Survey household income data. Nevertheless, it allows us to see the impact of the allowances. In the 2012/13 financial year, the DLA reduced the percentage of households with disabled children under the $60 \%$ of median household income before-housing-costs poverty measure by four percentage points. This meant that the gap between households with and without disabled children was less than one percentage point (Department for Work and Pensions and Office for National Statistics, 2014b, p.99; Department for Work and Pensions, 2018). This matches older research from 2008/09 which found that the DLA caused a four point drop in the percentage of children in households with disabled children under the $60 \%$ of median household income poverty threshold (Children's Society, 2011, p.10).

\section{Disabled children are more likely to live} in a one-parent household disabled children experiencing poverty in New Zealand is the disproportionate number of disabled children living in one-parent households. In the $2013 \mathrm{New}$ Zealand Disability Survey, 30\% of disabled children lived in one-parent households (23\% in just one-parent households and $7 \%$ in one parent with other people households). By comparison, 17\% of non-disabled children lived in one-parent
A key factor that increases the risk of 
Figure 2: The percentage of disabled children in household income levels by selected household composition

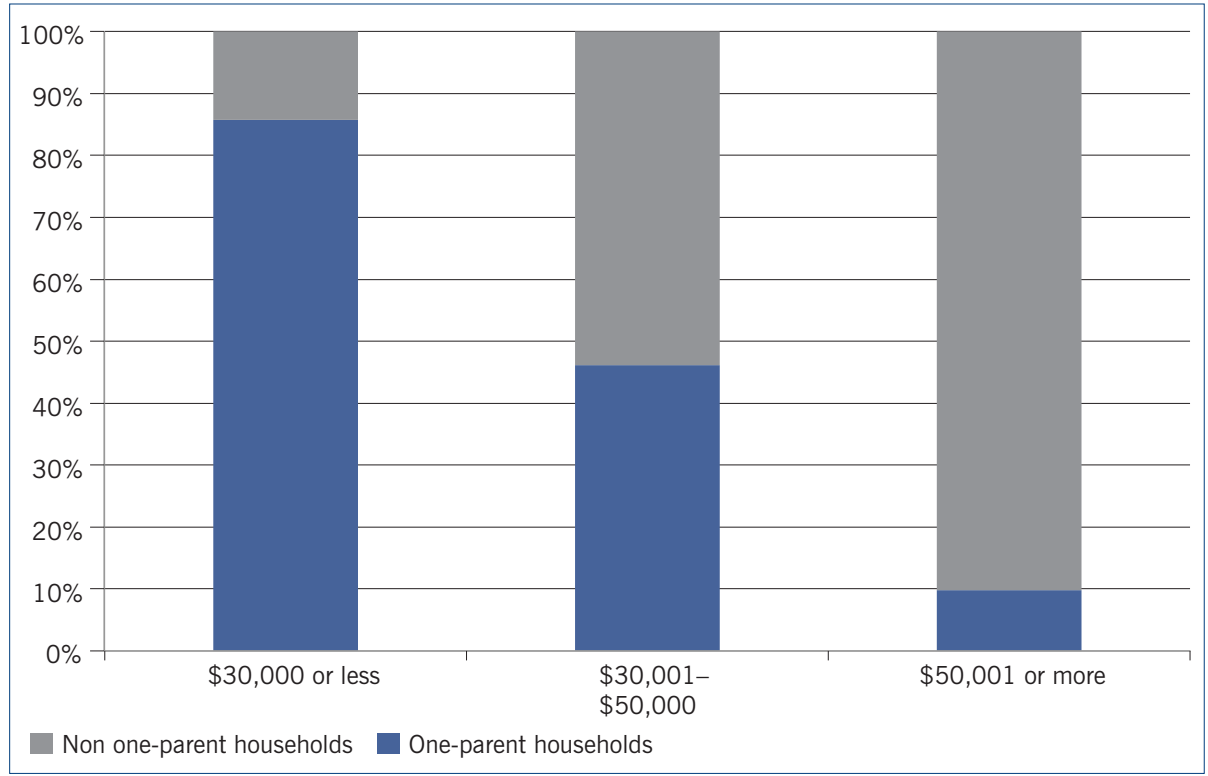

Note: the estimate for one-parent households in the $\$ 50,001$ or more income range had a sampling error between $30 \%$ and $50 \%$, due to low sample size.

Source: Statistics New Zealand, n.d.

Figure 3: Employment status 2013

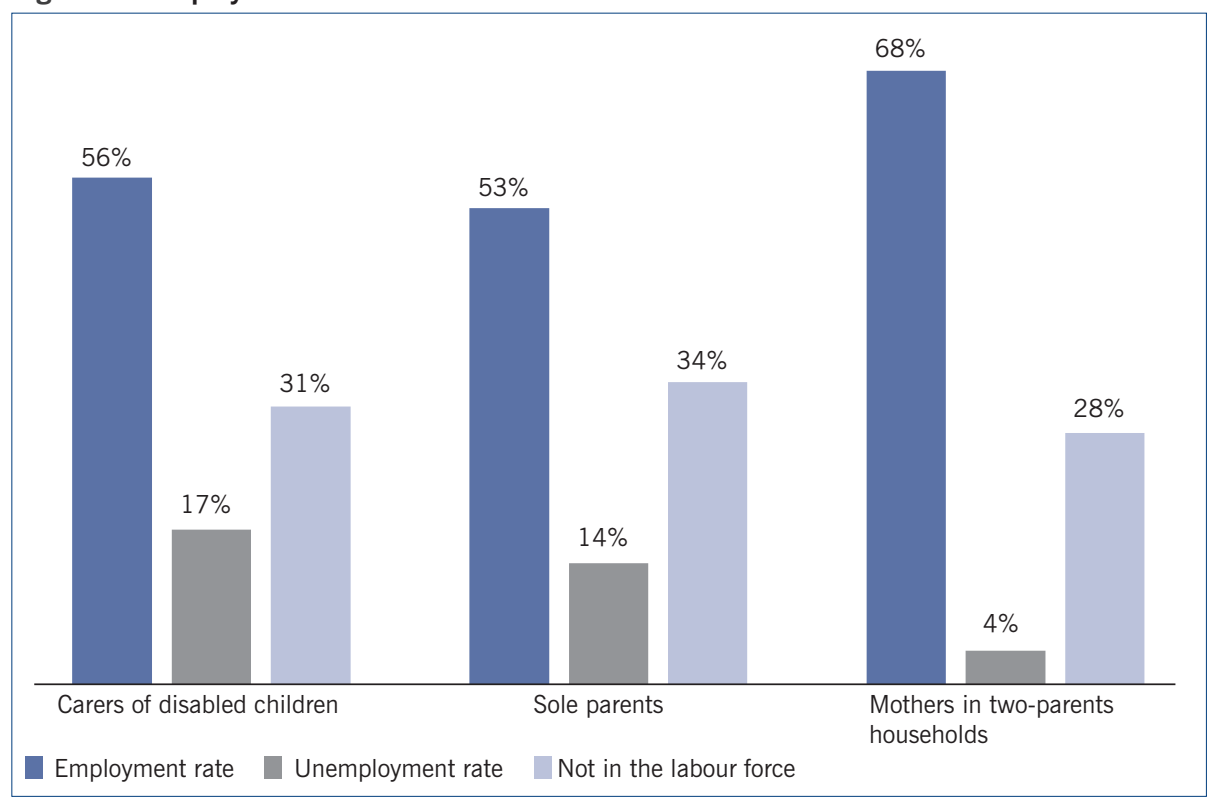

Source: Statistics New Zealand, n.d., 2014a, pp.11, 14-15

households $(14 \%$ in just one-parent households and 3\% in one parent with other people households) (Statistics New Zealand, 2016, p.4).

We should consider the increased chance of being in a one-parent household alongside data on carers/parents' wellbeing. In the 2013 Disability Survey, 60\% of carers/parents of disabled children reported not having enough time for themselves and $41.5 \%$ reported often feeling stressed in the last four weeks; a further $38.3 \%$ reported sometimes feeling stressed in the last four weeks (Statistics New Zealand, n.d.). This matches previous
New Zealand studies that have found high degrees of stress among carers of disabled adults and children (Milner, Mirfin-Veitch and Milner-Jones, 2016; Jorgensen et al., 2010). It is reasonable to assume that feeling stressed and lacking time may increase the chance of relationship breakdowns and prevent new relationships.

In New Zealand, one-parent households with disabled children make up most of the low-income households with disabled children (see Figure 2). 86\% of disabled children who live in households earning less than $\$ 30,000$ a year are in one-parent households (Statistics New Zealand, n.d.).
Unemployment is high among carers/parents of disabled children

In the 2013 Disability Survey, an estimated $17 \%$ of primary carers of disabled children were unemployed (see Figure 3) (Statistics new Zealand, n.d.). To be counted as unemployed the primary carer must have said they had looked for work in the last four weeks. This is a higher unemployment rate than for one-parent households in general or mothers in two-parent households.

Having a disabled child appears to have a similar effect on a primary carer's employment prospects as being a sole parent. A high number of carers of disabled adults and children report that providing care has had an impact on their employment. Carers also report that employment is valuable for them, both for its ability to improve their material well-being and for the social benefits (Milner, Mirfin-Veitch and Milner-Jones, 2016, pp.36-8).

The high rate of primary carers saying they want to work clashes with government policy, which has not prioritised support to help primary carers to work. In some cases, government policy is even hostile to the idea of primary carers working. For example, the government bans the use of the carer support subsidy while the carer is at work (Ministry of Health (2018a). This is significant because carer support is one of the main forms of support for carers/parents with a disabled child/young person under 19. As of September 2016, 12,129 carers/parents of a disabled child/ young person aged under 19 were allocated carer support (Ministry of Health, 2017, p.31). The Ministry of Health does plan to remove the ban on carers working while using carer support next year (Ministry of Health, 2018b).

\section{Income adequacy and extra costs}

The available evidence is clear that having a disability generates significant extra financial and time costs for disabled children and their whānau (Mitra et al., 2017, p.480; Brown, 2010, p.65). There is wide variation in the international data and research on the exact extra costs. Different research methods generate different estimates. What support the government provides or funds also makes a large difference. 
Extra costs mean that more income is needed for disabled people and their whānau to have the same opportunities as non-disabled people (Kuklys, 2004, p.28). They also mean that households with disabled family members may be effectively in poverty and/or material hardship at higher income levels than for households without disabled family members (Parish et al., 2009; Mont, 2014, p.5). UK estimates are that families with disabled children need 10-18\% higher incomes than similar families without disabled children to have the same living standard (Blackburn, Spencer and Read, 2010, p.9). This means that while the UK disability-related allowances and tax credits are effective at eliminating the increased risk of income poverty, they may still be insufficient to meet the full extra costs associated with disability. Families receiving these allowances may still be in material hardship (Children's Society, 2011).

While we lack data on extra costs for New Zealand disabled children, in the 2013 Disability Survey carers/parents of disabled children were asked about income adequacy. Some $63 \%$ of households with disabled children said they earn just enough or not enough money (see Figure 4). By comparison, only $43 \%$ of all households say they earn just enough or not enough money (Stats New Zealand, 2017 , n.d.). This lower level of income adequacy is likely to be the result of lower incomes and extra costs.

\section{The impact of partially funded support}

The way disability support services are provided may in fact increase inequality. Apart from ACC, disability-related support is often not designed to meet the full costs associated with disability. For example, carer support is a subsidy that only partially meets the costs of hiring a relief carer, although this may change next year with a major reform of carer support promised (Ministry of Health, 2018a, 2018b). In 2016 research, 66\% of carers of disabled people reported using their own financial resources to make up the difference between the carer support payment and the actual cost of respite; $22 \%$ of carers had spent more than $\$ 1,500$ a year on respite (Milner, Mirfin-Veitch and Milner-Jones, 2016, p.41).

Figure 4: Income adequacy 2013

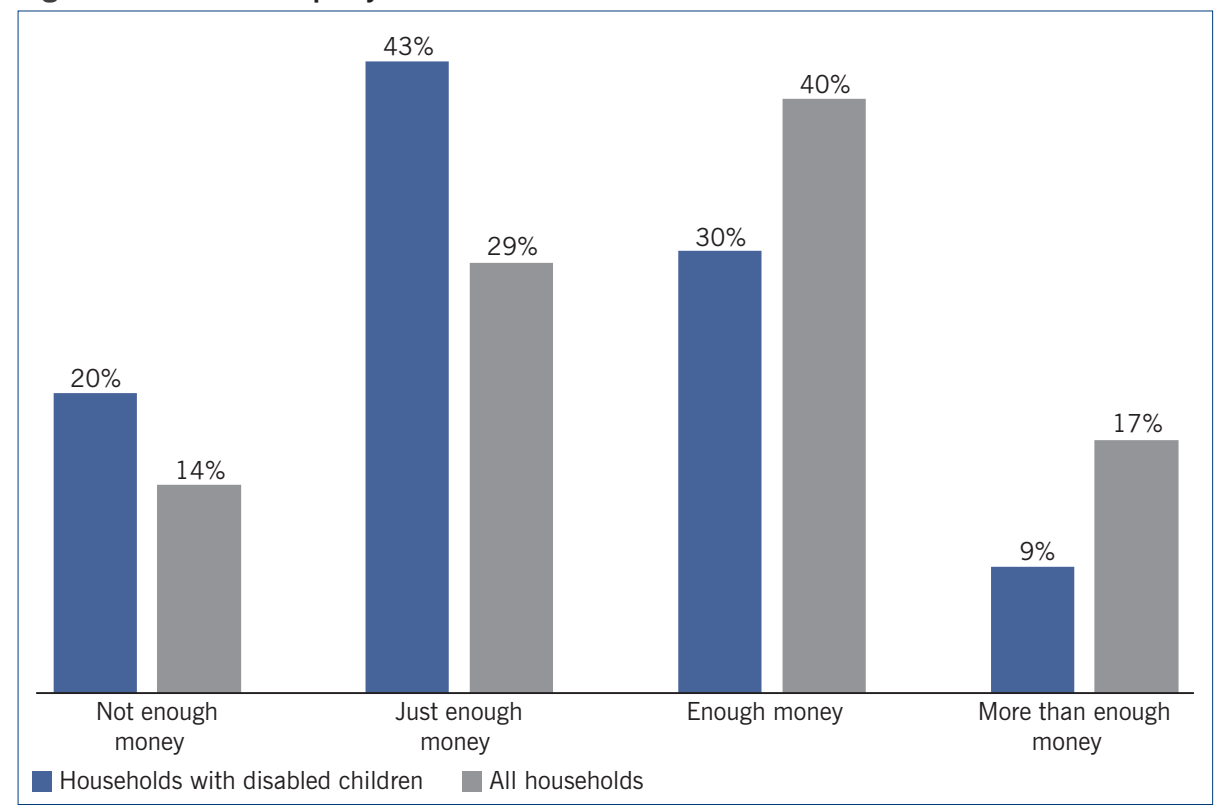

Source: Stats New Zealand, 2017, n.d.

Contributory support and subsidies are likely to be regressive for people with lower incomes and/or fewer natural supports. In other words, the ability to use partially funded support is likely to decrease for these people. A contributory disability support system may, therefore, increase inequality between higher and lower income whānau with disabled children, as well as between whānau with disabled children and whānau without disabled children.

\section{Decile data from the Ongoing \\ Resourcing Scheme}

One source of data through which to examine socio-economic trends amongst households with disabled children is the decile data on students who receive ORS funding. ORS is for students with high or very high learning support needs and funds support and services for those students (Ministry of Education, 2018). A relatively small number of students receive ORS funding: 6,661 students in 2008 and 9,049 students in 2017 (Indicators and Reporting Team, Ministry of Education, 2017a).

The school decile system measures five socio-economic indicators in meshblocks where students of each school live. ${ }^{3}$ This is based on data from the census and schools. The five indicators used, and weighted equally, are:

the percentage of households with equivalent income in the lowest $20 \%$, adjusted for the number of adults and children as well as the age of children; the percentage of employed parents in low-skill occupations;

the amount of household crowding; the percentage of parents with no qualifications; and

the percentage of parents on income support.

A decile 1 school is in the $10 \%$ of schools that have the highest proportion of students who live in disadvantaged meshblocks, according to these five indicators. (Note that while each decile has roughly the same number of schools, they do not necessarily have the same number of students (Ministry of Education, 2017c).)

The indicators are weighted by the number of students attending the school in each meshblock. This means that if students receiving ORS funding are few in number at a school and tend to live in different areas than other students at a school, then the school decile rating may not accurately represent the socioeconomic indicators in their meshblocks (ibid.). We can, however, compare two different types of school: special schools, where $92 \%$ of all students receive ORS funding, and all other schools, where only $0.74 \%$ of students do. ${ }^{4}$ I will use the term 'mainstream schools' as a generic term for all non-special schools.

It is possible that the students who receive ORS funding are not representative 
Table 2: Students at decile 1-5 and 6-10 schools in 2008 and 2017

\begin{tabular}{lrrr} 
& Total 2008 & Total 2017 & Increase \\
\hline All students at decile 1-5 schools & 317,502 & 320,273 & 2,771 \\
All students at decile 6-10 schools & 433,539 & 469,065 & 35,526 \\
$\begin{array}{l}\text { Students receiving ORS funding at } \\
\text { mainstream schools deciles 1-5 }\end{array}$ & 2,205 & 2,986 & 781 \\
$\begin{array}{l}\text { Students receiving ORS funding at } \\
\text { mainstream schools deciles 6-10 }\end{array}$ & 2,176 & 2,743 & 567 \\
$\begin{array}{l}\text { Students receiving ORS funding at special } \\
\text { schools deciles 1-5 }\end{array}$ & 1,942 & 2,599 & 657 \\
$\begin{array}{l}\text { Students receiving ORS funding at special } \\
\text { schools deciles 6-10 }\end{array}$ & 237 & 544 & 307 \\
\hline $\begin{array}{l}\text { Source: data from the Ministry of Education data requests team } \\
\text { nat }\end{array}$ & & & \\
\hline
\end{tabular}

of students with high or very high learning support needs. The ORS application process is meant to be collaborative between parents/carers and educators (Ministry of Education, 2017a). The application process, or eligibility criteria, could favour, or be easier for, certain groups of students, parents/carers and/or early childhood centres/schools. Despite the limitations, the ORS data is currently one of the most easily accessible and regularly updated data sources that can point to socio-economic trends for students with high and very high learning support needs.

The general trend between 2008 and 2017 was for the number of students in higher decile schools to increase by far more than the number of students in lower decile schools: $93 \%$ of the total increase in student numbers was in decile 6-10 schools. Students receiving ORS support do not follow that trend and see larger increases in decile $1-5$ schools. $^{5}$

Prior to 2008, students receiving ORS funding were already more likely to be attending a lower decile school, but the differing trends have widened the gap. Students receiving ORS support now make up $1.7 \%$ of all students in decile $1-5$ schools, an increase of $34 \%$ on the 2008 percentage, compared to $0.7 \%$ of all students in decile 6-10 schools, an increase of $26 \%$ on the 2008 percentage (Indicators and Reporting Team, Ministry of Education, 2017b, 2018b). As a result, in 2017 a student receiving ORS funding is $54 \%$ more likely to be in a decile $1-5$ school than all other students. The impact is greater on ethnic groups that are less likely to be attending a lower decile school in general. For example, European/Pākehā students receiving ORS funding are 103\% more likely to be in a decile $1-5$ school than all European/Pākehā students. Asian students receiving ORS funding are $96 \%$ more likely to be in a decile $1-5$ school than all Asian students (Indicators and Reporting Team, Ministry of Education, 2017b, 2018b).

Lower decile schools receive more general state funding per student and a slightly higher special education grant per student (Ministry of Education, 2017b). This may mean that lower decile mainstream schools are more welcoming of disabled students and/or have better facilities. This, in turn, may make it more likely for a student receiving ORS support to attend a lower decile mainstream school, even if the student does not live in a lower decile neighbourhood. This may drive some of the trend we see for students receiving ORS funding at mainstream schools. It cannot, however, drive the trend for students receiving ORS funding at special schools. Students receiving ORS funding are the overwhelming majority of students at special schools, so the decile data will accurately reflect the neighbourhoods they live in.

\section{Discussion}

The 2013 Disability Survey data shows that households with disabled children are more likely to be under the $39.2 \%$, $47 \%$ and $62.7 \%$ of median household income (total/gross and before housing costs) thresholds than all households with children. This data also shows that disabled children are more likely to live in oneparent households and that their primary carer is more likely to be unemployed.
The ORS data covers changes over time amongst a smaller, and possibly less representative, group of disabled children/ young people with high learning support needs. The ORS data suggests that trends for disabled children/young people can run counter to those for other children/young people. In particular, between 2008 and 2017, students receiving ORS funding failed to follow the general trend towards students living in less socio-economically disadvantaged neighbourhoods.

Linking the two data sources together suggests that this lack of improvement may occur because disabled children are more likely to live in one-parent households. Further, even when the disabled child is not in a one-parent household, the impact of disability has similar effects on the primary carer's employment prospects as if they were a sole parent. In addition, there is the impact of extra financial and time costs associated with disability, including the time costs involved in accessing and using government-funded support. These extra costs can increase the material hardship of the household, as well as make economic and educational participation more difficult for carers/parents and for children. Partially funded support is likely to help only some carers/parents meet these costs, specifically those with higher incomes and/or more natural support.

As a result, households with disabled children may be unable to take advantage of improving economic and educational opportunities to the same degree as households with non-disabled children. For example, the growing employment rate since 2013 is unlikely to benefit households with disabled children as much as households without disabled children (Stats New Zealand, 2018b). This would put households with disabled children at a disadvantage, greatly increasing the risk of relative poverty.

The United Kingdom data shows that sufficient disability-related allowances and disability-specific tax credits can sharply reduce the increased risk of income poverty. There is a clear case for increasing the payment rate of the current New Zealand disability-related allowances, and for exploring disability-specific tax credits. Alongside higher disability-related allowances, we need to improve the ability 
of support to help a carer/parent work, switch partially funded support to fully funded support, and provide more support to reduce the stress of carers/parents and/ or give them more time. This, in turn, should reduce the unemployment rate of carers/parents, as well as help prevent relationship breakdowns or enable sole parents to find new relationships.

The key to reducing inequality between households with and without disabled children is to enable the carers/parents of disabled children to benefit more from improving economic and educational opportunities, either directly through support to work and study or indirectly through greater income redistribution, or, preferably, both.

\section{Data gaps}

Disability identification questions are currently not included in the crucial Household Economic Survey. This is the key to getting better data on households with disabled children, including data on disposable income and income after housing costs, as well as income adjusted for household composition. Stats New Zealand is actively exploring ways to integrate a disability screening question set into the Household Economic Survey. The challenge is to develop a relatively short question set that adequately identifies a broad and inclusive sample of disabled children and adults.

Unfortunately, the main disability identification question set now being used by Stats New Zealand, the Washington Group on Disability Statistics short set, is unsuitable for collecting data on disabled children (Statistics New Zealand, 2015, p.10; Washington Group on Disability Statistics, 2017, p.3). This is because disabled children have a very different impairment profile to adults in New
Zealand. The two most common impairment types for disabled children are learning and psychological impairments, two areas the short set does not adequately cover. The main areas covered by the short set are areas where disabled children are under-represented, with the exception of communication/speaking (Statistics New Zealand, 2014d; Washington Group on Disability Statistics, 2010).

One possible solution is to use the child functioning question sets developed by the Washington Group and UNICEF (Washington Group on Disability Statistics, 2016). The length of the child functioning question sets is a barrier, however, to their inclusion in non-disability-specific surveys. A solution could be for Stats New Zealand in partnership with others, including nongovernment organisations, to develop a shorter localised version of the child functioning question sets. An alternative would be a shorter version of the questions for children used in the 2013 Disability Survey.

Until a reasonably short, but reliable, question set is developed for measuring disability status in children, we are likely to lack data on disabled children and their whānau. Without reliable data on disabled children and their experiences, they will be largely invisible in current data initiatives, such as Treasury's Living Standards Dashboard, the targets in the Child Poverty Reduction Bill, and Stats New Zealand's Indicators Aotearoa New Zealand (Smith, 2018; Stats New Zealand, 2018). This is unacceptable from a human rights and social justice point of view, because disabled children and their whānau are among the most disadvantaged and discriminated against groups in society. For this reason, United Nations agencies, disabled persons organisations and nongovernment organisations recommend that immediate action is taken by national statistics offices to disaggregate more data on disability, especially data on the UN Sustainable Development Goals (Interagency and Expert Group on SDG Indicators, 2016).

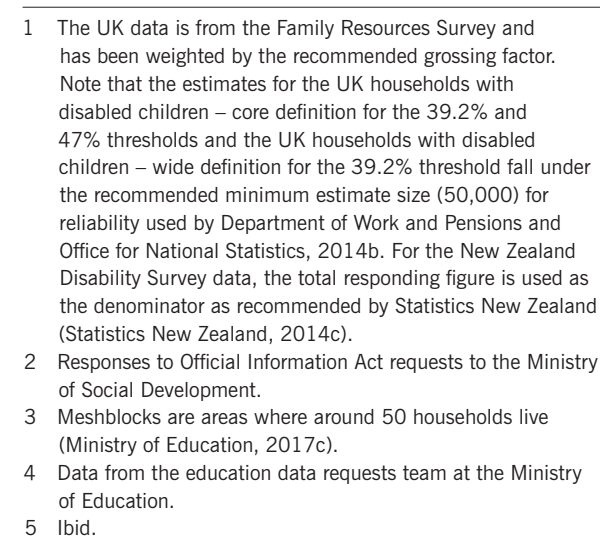

\section{Acknowledgements}

I would like to acknowledge the following people who provided very helpful feedback on drafts of this article: Sophie Butt, Sarah Dietrich, John Kerr, Jared Humm, Jonathan Boston, Dr Brigit Mirfin-Veitch, Paul Milner and Nicholas Svensen. Very helpful and insightful peer review was provided by Dr Claire Achmad. I would also like to acknowledge the customised data team at Stats New Zealand, particularly Dean Edwards, the education data requests team at the Ministry of Education, particularly Bea Wooding, and the official and parliamentary information team at the Ministry of Social Development. I would last but not least like to acknowledge my employer, CCS Disability Action, and particularly my manager, Kellyanne Tong. CCS Disability Action paid for the customised data from Statistics New Zealand and encouraged my work. All errors and views in this article are my own.

\section{References}

Australian Council of Social Service and the Social Policy Research Centre (2016) Poverty in Australia 2016, Strawberry Hills: Australian Council of Social Service

Blackburn, C.M., N.J. Spencer and J.M. Read (2010) 'Prevalence of childhood disability and the characteristics and circumstances of disabled children in the UK: secondary analysis of the Family Resources Survey', BMC Pediatrics

Boston, J. (2017) 'Alleviating poverty: issues and options', Policy Quarterly, 13 (3), pp.27-34

Browne, N.J. (2010) 'Quality of life for caregivers of a child aged 6-16 years with autistic spectrum disorder and/or an intellectual disability: a comparative study', MA thesis, Massey University

Children's Society (2011) 4 in Every 10: disabled children living in poverty, London: Children's Society

Committee on the Rights of the Child (2007) 'General comment no 9', 27 February, United Nations Human Rights Office of the High Commissioner: http://www2.ohchr.org/english/bodies/crc/docs/GC9 en.doc 
Committee on the Rights of Persons with Disabilities (2017) 'General comment no 5 (2017) on living independently and being included in the community', 27 October, United Nations Human Rights Office of the High Commissioner, https://tbinternet.ohchr.org/_layouts/ treatybodyexternal/Download.aspx?symbolno $=\mathrm{CRPD} / \mathrm{C} /$ GC/5andLang=en

Department for Work and Pensions (2013) 'Benefit and pension rates: April 2013', 12 November, https://www.gov.uk/government/uploads/ system/uploads/attachment_data/file/256532/benefit-rates.csv/preview Department for Work and Pensions (2018) Stat-Xplore, https://stat-xplore. dwp.gov.uk/

Department for Work and Pensions and Office for National Statistics (2014a) Family Resources Survey United Kingdom, 2012/13, London: Department for Work and Pensions and Office for National Statistics

Department for Work and Pensions and Office for National Statistics (2014b) Households Below Average Income 1994/95-2012/13: an analysis of the income distribution 1994/95-2012/13, London: Department for Work and Pensions

Expert Advisory Group on Solutions to Child Poverty (2012) 'Working paper no.21: child poverty and disability', http://www.occ.org.nz/ assets/Uploads/EAG/Working-papers/No-21-Child-poverty-anddisability.pdf

Indicators and Reporting Team, Ministry of Education (2017a) 'Number of students by time series 2005-2017', November, https://www. educationcounts.govt.nz/_data/assets/excel_doc/0005/146255/ Number-of-Students-by-Time-series-2005-2017.xls

Indicators and Reporting Team, Ministry of Education (2017b) 'ORS by student decile and ethnicity 2005-2017', November, https://www. educationcounts.govt.nz/_data/assets/excel_doc/0020/172154/ ORS-by-Student-Decile-and-Ethnicity-2005-2017.xls

Indicators and Reporting Team, Ministry of Education (2018a) 'School decile and student ethnicity', https://www.educationcounts.govt. nz/_data/assets/excel_doc/0011/71786/Ethnicity-and-Decile.xlsx

Indicators and Reporting Team, Ministry of Education (2018b) 'Time series data for trend analysis 1996-2017', https://www.educationcounts. govt.nz/_data/assets/excel_doc/0011/71768/TimeSeries-1996-2017.xIsx

Inland Revenue (2013) 'Currency rates 2012-2013 - end of month rates', https://www.ird.govt.nz/resources/e/9/ e9fa70004b3cd4b18b1ccbca8e654715/end-month-ratesmarch-2013.pdf

Inter-agency and Expert Group on SDG Indicators (2016) 'Disability data disaggregation: joint statement by the disability sector', November, Washington Group on Disability Statistics, http://www. washingtongroup-disability.com/wp-content/uploads/2016/01/ Joint-statement-on-disaggregation-of-data-by-disability-Final.pdf Jorgensen, D., M. Parsons, S. Jacobs and H. Arksey (2010) 'The New Zealand informal caregivers and their unmet needs', New Zealand Medical Journal, 123 (1317), pp.9-16

Kuklys, W. (2004) 'A monetary approach to capability measurement of the disabled: evidence from the UK', University of Cambridge

Milner, P., B. Mirfin-Veitch and M. Milner-Jones (2016) 'You care about me when you care about my son': an exploration of the respite experiences of New Zealand carers, Dunedin: Donald Beasley Institute

Ministry of Education (2017a) 'Apply for Ongoing Resourcing Scheme (ORS)', 17 November, https://www.education.govt.nz/school/ student-support/special-education/ors/apply-for-ors/
Ministry of Education (2017b) 'Operational funding rates 2017 and 2018', 19 September, https://www.education.govt.nz/assets/Documents/ School/Running-a-school/Resourcing/Operational-GrantRates-2017-2018.pdf

Ministry of Education (2017c) 'School deciles', 3 December, https://www. education.govt.nz/school/running-a-school/resourcing/operationalfunding/school-decile-ratings/

Ministry of Education (2018) 'Overview of Ongoing Resourcing Scheme (ORS)', 16 March, https://www.education.govt.nz/school/studentsupport/special-education/ors/overview-of-ors/

Ministry of Health (2015) Demographic Information on Clients Using the Ministry of Health's Disability Support Services as at September 2013, Wellington: Ministry of Health

Ministry of Health (2017) Demographic Report on Clients Allocated the Ministry of Health's Disability Support Services, Wellington: Ministry of Health

Ministry of Health (2018a) 'Carer support', 9 March, https://www.health. govt.nz/your-health/services-and-support/disability-services/typesdisability-support/respite-and-carer-support/carer-support

Ministry of Health (2018b) 'I choose', 14 September, https://www.health. govt.nz/your-health/services-and-support/disability-services/typesdisability-support/respite/i-choose

Mitra, S., M. Palmer, H. Kim, D. Mont and N. Groce (2017) 'Extra costs of living with a disability: a review and agenda for research', Disability and Health Journal, 10 (4), pp.475-84

Mont, D. (2014) Childhood Disability and Poverty, working paper 25, London: Leonard Cheshire Disability and Inclusive Development Centre, University College London

National Archives (n.d.) 'Tables confirming tax and tax credit rates and thresholds for 2012-13', http://webarchive.nationalarchives.gov. uk/20130103003552/http://cdn.hm-treasury.gov.uk/as2011_rates_ and_thresholds_201213.pdf

New Zealand Government (2001) New Zealand Disability Strategy: making a world of difference - whakanui oranga, Wellington: Ministry of Health Office for Disability Issues (2016) New Zealand Disability Strategy 2016-2026, Wellington: Ministry of Social Development

Office for National Statistics (2015) 'Harmonised concepts and questions for social data sources primary principles long-lasting health conditions and illnesses; impairments and disability', http://webarchive. nationalarchives.gov.uk/20160106185646/http://www.ons.gov.uk/ ons/guide-method/harmonisation/primary-set-of-harmonised-conceptsand-questions/long-lasting-health-conditions-and-illnesses-impairments-and-disability.pdf

Office for National Statistics (2017) 'Population estimates: analysis tool', 22 June, https://www.ons.gov.uk/peoplepopulationandcommunity/ populationandmigration/populationestimates/datasets/ populationestimatesanalysistool

Parish, S.L., R.A. Rose, M. Andrews, M. Grinstein-Weiss, E.L. Richman and S. Dababnah (2009) 'Material hardship in US families raising children with disabilities: research summary and policy implications', Chapel Hill: UNC School of Social Work

Revenue Benefits (2018) 'Tax credits: understanding disability', 18 April, https://revenuebenefits.org.uk/tax-credits/guidance/how-do-tax-creditswork/understanding-disability/\#Children\%20and\%20disability

Smith, C. (2018) Treasury Living Standards Dashboard: monitoring intergenerational wellbeing, Wellington: New Zealand Treasury 
Statistics New Zealand (n.d.) Customised report from the 2013 Disability Survey, licensed by Statistics New Zealand for re-use under the Creative Commons Attribution 4.0 International licence, available on request from the author

Statistics New Zealand (2014a) 2013 Census QuickStats about families and households, Wellington: Statistics New Zealand

Statistics New Zealand (2014b) 2013 Census QuickStats about income, http://archive.stats.govt.nz/ /media/Statistics/Census/2013\%20 Census/profile-and-summary-reports/quickstats-about-income/ quickstats-income.pdf

Statistics New Zealand (2014c) '2013 Disability Survey social and economic outcome tables', 7 October, http://www.stats.govt.nz/ browse_for_stats/health/disabilities/disability-survey-2013-additionaltables.aspx

Statistics New Zealand (2014d) Disability Survey: 2013, Wellington: Statistics New Zealand

Statistics New Zealand (2014e) 'Disability Survey: 2013 definitions', http://archive.stats.govt.nz/browse_for_stats/health/disabilities/ DisabilitySurvey_HOTP2013/Definitions.aspx

Statistics New Zealand (2015) Measuring Disability in New Zealand: current status and issues: a discussion document for the Working Group on Disability Data and Evidence, Wellington: Statistics New Zealand

Statistics New Zealand (2016) Disability and Housing Conditions: 2013, Wellington: Statistics New Zealand

Stats New Zealand (2017) 'Nearly two-thirds of households say they make enough to live on - corrected', 19 October, https://www.stats.govt.nz/ news/nearly-two-thirds-of-households-say-they-make-enough-to-live-on

Stats New Zealand (2018a) 'Age by sex, for the census night population count, 1996, 2001, 2006, and 2013 censuses (RC, TA, AU)', http:// nzdotstat.stats.govt.nz/wbos/Index.aspx? DataSetCode=TABLECODE80
11 and_ga $=2.11856823 .2022501111 .1530493768$ 825274221.1530493768\#

Stats New Zealand (2018b) Indicators Aotearoa New Zealand - Ngä Tütohu Aotearoa: consultation, 31 July, https://www.stats.govt.nz/ consultations/indicators-aotearoa-new-zealand-nga-tutohu-aotearoaconsultation

Stats New Zealand (2018c) 'Labour market statistics: March 2018 quarter', 2 May, https://www.stats.govt.nz/information-releases/ labour-market-statistics-march-2018-quarter

Suri, J. and A. Johnson (2016) Barriers to Support: uptake of the child disability allowance in Otara, Auckland: Child Poverty Action Group

UK Data Service (2018) 'Family Resources Survey', https://discover. ukdataservice.ac.uk/series/?sn=200017

Washington Group on Disability Statistics (2010) 'Short set of questions on disability', 31 March, https://www.cdc.gov/nchs/washington_group/ wg_questions.htm

Washington Group on Disability Statistics (2016) 'Child functioning question sets', 18 December, www.washingtongroup-disability.com/ washington-group-question-sets/child-disability/

Washington Group on Disability Statistics (2017) 'The data collection tools developed by the Washington Group on Disability Statistics and their recommended use', 23 October, http://www.washingtongroupdisability.com/wp-content/uploads/2016/12/WG-Document-1-DataCollection-Tools-Developed-by-the-Washington-Group.pdf

Work and Income (2013) 'Benefit rates April 2013', https://www. workandincome.govt.nz/products/benefit-rates/benefit-rates-april-2013. html\#null

Wynd, D. (2015) 'It shouldn't be this hard': children, poverty and disability, Auckland: Child Poverty Action Group

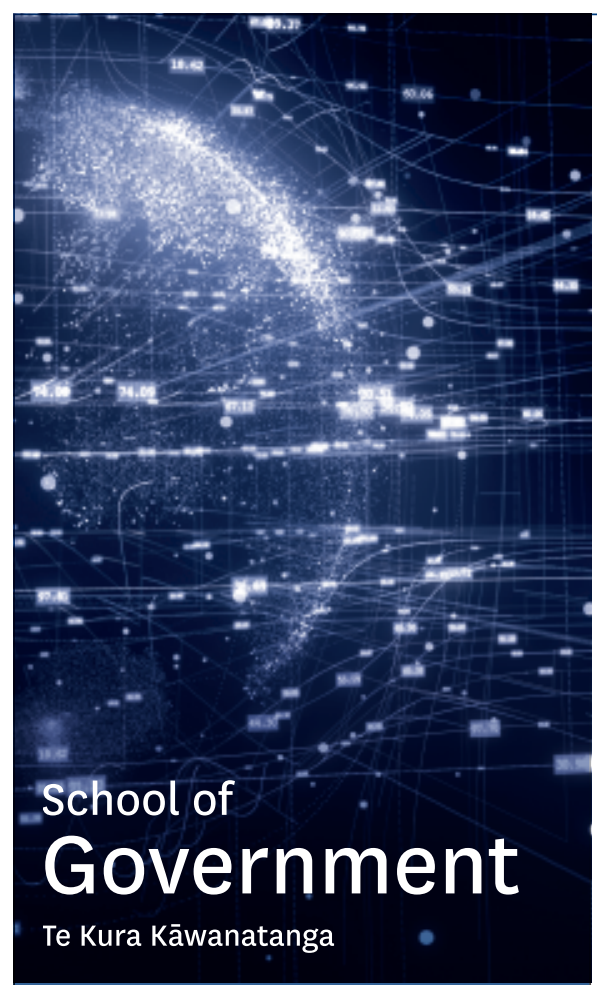

\section{School of Government Brown Bag seminars - open to all}

Join lively, topical presentations and discussions in an informal setting at the School of Government. These Brown Bag sessions are held the first Monday of most months, over lunchtime. Past topics have included:

- Intergenerational wellbeing and public policy

- A visual exploration of video surveillance camera policy and practice

The role of financial risk in the New
Zealand Primary Health Care Strategy

- Strategic public procurement: a research agenda

- What role(s) for Local Government: 'roads, rates and rubbish' or 'partner in governance'?

- Human capital theory: the end of a research programme?

- How do we do things?

We would welcome your attendance and/or guest presentation, if you are interested.

Contact us to go on the mailing list for upcoming sessions at sog-info@vuw.ac.nz 